\title{
NITROGEN STORAGE FOLLOWING INTRAVENOUS AND ORAL ADMINISTRATION OF CASEIN HYDROLYSATE TO IN- FANTS WITH ACUTE GASTRO-INTESTINAL DISTURBANCE ${ }^{1}$
}

\author{
BY ALFRED T. SHOHL \\ (From the Department of Pediatrics, Harvard Medical School, and the Infants' Hospital and \\ the Children's Hospital, Boston)
}

(Received for publication Nov. 2, 1942)

The acute gastro-intestinal disturbances of infants have always been a source of anxiety to the pediatrician. Nutritional therapy has made severe demands upon his skill. The two horns of the dilemma are, first, that any kind of food by mouth may lead to increase of untoward symptoms already present, i.e. diarrhea and vomiting; and second, that deprivation of food for a relatively short time may lead to collapse. The accompanying dehydration and acidosis are complications which often cause a fatal outcome. We have learned, over the course of the last few decades, how to replenish the interstitial fluids, to overcome the acidosis, and to provide for a substantial portion of the caloric requirement by parenteral therapy. This, coupled with the use of sulfonamides when indicated, constitutes such great improvement in therapy that modern clinicians with good hospital facilities no longer have the same dread of these diseases as those of a generation ago.

But these procedures still do not provide nitrogen, which is essential for normal nutrition. Protein or its equivalent could, until fairly recently, be supplied only by intravenous plasma infusions. Another source of nitrogen is now available for intravenous use,-protein hydrolysate. Such a preparation has already been shown to be an adequate source of nitrogen for the nutrition of infants who are not ill, whether given orally or intravenously (1).

The question arose as to how large a nitrogen loss infants with acute gastro-intestinal disorders suffer, and whether amino acid therapy would change a negative to a positive balance. The purpose of this study was to make a quantitative determination of the effect upon nitrogen balances

\footnotetext{
1 This investigation was aided by a grant from Mead Johnson and Co.
}

of enteral and parenteral administration of casein hydrolysate to infants suffering from acute gastrointestinal symptoms. In order to avoid undue complexity, analysis of the clinical aspect is included only in so far as it is pertinent.

\section{EXPERIMENTAL}

The 20 male infants included in this study were patients sent to the hospital because they were too ill to be treated as out-patients. The main features of the illnesses were vomiting, diarrhea, and fever, with or without infection, which led to dehydration and sometimes acidosis of such a grade as to require parenteral fluid therapy and withholding of food by mouth. This group did not include any patients with specific intestinal infections such as dysentery or typhoid fever. The infants were from 2 weeks to 8 months of age, and from 2.6 to $9 \mathrm{kgm}$. in weight.

Saline solution was given intravenously to replenish depleted body fluids. Glucose-lactate solution was given when necessary to alleviate acidosis. Nitrogen was provided as casein hydrolysate, given intravenously or orally. Specific drugs were given as indicated.

Some of the infants were selected for this study immediately following admission to the hospital; others were given fluids parenterally, but no nitrogen, for 1 or 2 days before administration of casein hydrolysate was begun. Blood transfusions were given in several cases before and during the time of casein hydrolysate administration.

The preparation used for intravenous administration was an enzymic hydrolysate of casein plus glucose in solution.2 This was sometimes modified in our laboratory, but contained, as given, 2.5 to 4 per cent casein hydrolysate, 5 to 10 per cent glucose, and varying amounts of $\mathrm{NaCl}$. We also used, for oral administration, a prepared food containing casein hydrolysate, ${ }^{3}$ which we had

2 This material, the trade name of which is "Amigen," was prepared and supplied through the courtesy of Mead Johnson and Co. Amigen contains no unhydrolyzed protein. The nitrogen is present in various forms; about 60 per cent is amino nitrogen.

- This was a mixture of 20 per cent casein hydrolysate (Amigen), 42.3 per cent dextri-maltose, 10 per cent starch, 18 per cent olive oil, 3 per cent brewers' yeast, 
used in previous studies (1), and which had been found to be adequate to meet nutritional needs of infants for protracted periods (2).

Each of the infants was placed upon a metabolism bed. When there was more than one period of observation, they were consecutive. Most of the periods were of 3 days' duration. Some as short as 24 hours were periods during which intravenous therapy only was given, and were short because of change either in clinical condition or in type of therapy. The urine and feces were collected and analyzed separately for nitrogen by the micro Kjeldahl method. The nitrogen intake also was determined by analysis.

The plan was to omit food by mouth and to give casein hydrolysate-glucose-saline solution intravenously for 24 to 48 hours, or until the vomiting ceased and the diarrhea subsided. The second phase of the treatment was to give the same or similar solution orally instead of, or in addition to, intravenously. If this form of treatment was well tolerated, the third phase was begun, namely, the casein hydrolysate food (containing starch and fat) or milk formula was given instead of, or in addition to, the casein hydrolysate solution. In a few cases, we have continuous observations on these three phases of treatment. Inasmuch as no two clinical cases are exactly alike, such a division is arbitrary and represents a clinical judgment in each case rather than a well defined division into stages of progress toward recovery. The phases of treatment correspond roughly with the stages of improvement in clinical condition. When recovery was sufficiently advanced, the infant was returned to milk formula feeding. In conformity with the accepted procedure, smaller amounts of material were given when the symptoms were most acute, and quantities were increased as the patient's condition improved. The caloric intake amounted to 40 to 90 Calories per $\mathrm{kgm}$. of body weight per day. These values are below the optimal for normal nutrition, but higher than usually given in these cases. In general, the lower caloric intakes were associated with the lower nitrogen intakes and the two increased together.

The solution was given intravenously, by constant drip through a No. 22 or No. 24 needle, into a scalp, arm, or leg vein, and allowed to flow by gravity at the rate of about 20 drops per minute, or 50 cc. per hour. Due largely to procedures which we no longer regard as correct, local edema and erythema developed in about one fourth of the patients. In every case, the edema subsided within a few hours after the needle was removed. It tended to be more severe when the injection was continued more than 10 or 12 hours, and when the lower extremities were used. The solution may have leaked through the puncture holes in the veins. Further, intact

and 6.7 per cent salts. This product was prepared by and supplied through the courtesy of Mead Johnson and Co. A Mead Johnson product is now available under the trade name of "Nutramigen" which is identical with the preparation we used except that it contains corn oil instead of olive oil. vessels which would prevent the passage of plasma protein would permit permeation of the small molecules of amino acids. If the amino acids spread into the tissues, there is every reason to believe that they were subsequently reabsorbed and utilized. In addition, as mentioned above, our solutions contained $\mathrm{NaCl}$ above that present in the casein hydrolysate. This led to increased water retention as is evidenced by the weight curves of the infants. The amount of $\mathrm{NaCl}$ present in the original product is sufficient to assure proper hydration of the tissues, and the excess merely tended to increase the local edema. Since we have abandoned the use of extra $\mathrm{NaCl}$ and have decreased the time of injection to less than 8 hours, we are no longer troubled with the edema which we encountered in these studies.

The temperature elevations accompanying intravenous administration of casein hydrolysate, which were reported previously, were not prominent in a single case, and were either absent or negligible. No injection had to be interrupted for this cause. This was probably due to an improvement in the preparation of the material. Extra precautions were taken so that the water used was free of pyrogenic material.

In this series, all the infants, with 2 exceptions, made good recoveries. It is our impression that the improvement was as good or better than could be obtained without amino acid therapy. Two died, W. McG. of bacterial pericarditis and $\mathbf{S}$. $\mathrm{K}$. of septicemia, diseases which they had when they were admitted to the hospital. Diarrhea was in both cases a presenting symptom. Of the others, except for S. P., who had a "break" in the last period, with vomiting and diarrhea, all the patients made more or less uneventful progress.

Observations were made upon 4 infants with approximately the same type and degree of illness, who did not receive amino acid therapy. Two (T. S. and J. T.) were given the usual glucose and saline parenterally, and 2 (R. F. and J. W.) received milk formulas by mouth. These served as controls.

\section{RESULTS AND DISCUSSION}

The data for nitrogen intake, output, and balance are summarized in Table $\mathrm{I}$. The details of the composition and concentration of injected and ingested material, length of periods, rate of intravenous administration, and volume of intake and output are not included, as they are similar to cases already reported $(1,3)$ and do not give any information necessary to this exposition. In order that the data on infants of different sizes and on periods of different lengths may more readily be compared, all results have been expressed as grams of nitrogen per day (24 hours) or as grams per $\mathrm{kgm}$. of body weight per day. For approximation data, calculation of metabolism on the basis of body weight is simpler than on the 
CASEIN HYDROLYSATE AND NITROGEN STORAGE

TABLE I

Nitrogen metabolism of infants with acute gastro-intestinal disturbance

\begin{tabular}{|c|c|c|c|c|c|c|c|c|c|c|c|}
\hline \multicolumn{3}{|c|}{ Subject } & \multicolumn{4}{|c|}{ Intake* } & \multicolumn{2}{|c|}{ Output } & \multicolumn{3}{|c|}{ Balance } \\
\hline$\underset{\text { age }}{\text { Name and }}$ & Phaset & Weight $t$ & Material & Method & N per day & $\begin{array}{c}\text { N per } \\
\text { kgm. per } \\
\text { day }\end{array}$ & Urine & Feces & N per day & $\begin{array}{l}\text { N, per cent } \\
\text { of intake }\end{array}$ & $\begin{array}{c}\text { N per } \\
\text { kgm. per } \\
\text { day }\end{array}$ \\
\hline \multirow{5}{*}{$\begin{array}{l}\text { R. C. } \\
8 \\
\text { months }\end{array}$} & I & $\begin{array}{l}\mathrm{kgm} . \\
8.30\end{array}$ & cas. hyd. & i.v. & $\begin{array}{l}\text { grams } \\
5.50\end{array}$ & $\begin{array}{l}\text { grams } \\
0.67\end{array}$ & $\begin{array}{l}\text { grams } \\
2.85\end{array}$ & $\begin{array}{l}\text { grams } \\
0.01\end{array}$ & $\begin{array}{c}\text { grams } \\
2.64\end{array}$ & 48 & $\begin{array}{c}\text { grams } \\
0.32\end{array}$ \\
\hline & II & 8.40 & cas. hyd. \{ & $\begin{array}{l}\text { i.v. } \\
\text { oral }\end{array}$ & $\begin{array}{l}0.60 \\
2.40\end{array}$ & 0.36 & 1.37 & 0.15 & 1.48 & 50 & 0.18 \\
\hline & II & 8.60 & $\begin{array}{l}\text { cas. hyd. } \\
\text { blood }\end{array}$ & $\begin{array}{l}\text { i.v. } \\
\text { oral } \\
\text { i.v. }\end{array}$ & $\begin{array}{l}3.86 \\
0.11 \\
3.07\end{array}$ & 1.28 & 3.04 & 0 & 4.00 & 57 & 0.47 \\
\hline & III & 9.00 & $\begin{array}{l}\text { cas. hyd. } \\
\text { c.h.f. } \\
\text { blood }\end{array}$ & $\begin{array}{l}\text { i.v. } \\
\text { oral } \\
\text { i.v. }\end{array}$ & $\begin{array}{l}2.32 \\
1.00 \\
1.60\end{array}$ & 0.54 & 1.33 & 0.23 & 3.36 & 68 & 0.37 \\
\hline & III & 9.60 & c.h.f. & oral & 2.85 & 0.30 & 1.45 & 0.48 & 0.93 & 33 & 0.10 \\
\hline \multirow{3}{*}{$\begin{array}{l}\text { S. C. } \\
3 \\
\text { months }\end{array}$} & I & 3.14 & cas. hyd. & i.v. & 1.53 & 0.49 & 0.74 & 0.05 & 0.74 & 48 & 0.24 \\
\hline & II & 3.17 & cas. hyd. & $\begin{array}{l}\text { i.v. } \\
\text { oral }\end{array}$ & $\begin{array}{l}0.10 \\
2.52\end{array}$ & 0.80 & 0.81 & 0.34 & 1.47 & 56 & 0.47 \\
\hline & III & 3.20 & $\begin{array}{l}\text { cas. hyd. } \\
\text { c.h.f. }\end{array}$ & $\begin{array}{l}\text { oral } \\
\text { oral }\end{array}$ & 1.76 & 0.55 & 0.94 & 0.10 & 0.72 & 41 & 0.22 \\
\hline \multirow{3}{*}{$\begin{array}{l}\text { D. D. } \\
2 \\
\text { weeks }\end{array}$} & I & 2.70 & cas. hyd. & i.v. & 1.48 & 0.55 & 0.56 & 0.27 & 0.65 & 43 & 0.24 \\
\hline & III & 2.85 & $\begin{array}{l}\text { cas. hyd. } \\
\text { c.h.f. } \\
\text { blood }\end{array}$ & $\begin{array}{l}\text { oral } \\
\text { oral } \\
\text { i.v. }\end{array}$ & $\begin{array}{l}0.27 \\
0.97\end{array}$ & 0.44 & 0.55 & 0.26 & 0.43 & 34 & 0.15 \\
\hline & III & 3.00 & c.h.f. & oral & 1.33 & 0.44 & 0.37 & 0.31 & 0.65 & 49 & 0.21 \\
\hline \multirow{6}{*}{$\begin{array}{c}\text { R. McK. } \\
1 \\
\text { month }\end{array}$} & II & 2.85 & $\begin{array}{l}\text { cas. hyd. } \\
\text { blood }\end{array}$ & $\begin{array}{l}\text { oral } \\
\text { i.v. }\end{array}$ & $\begin{array}{l}1.05 \\
0.81\end{array}$ & 0.66 & 0.31 & 0.32 & 1.23 & 66 & 0.43 \\
\hline & I & 2.79 & $\begin{array}{l}\text { cas. hyd. } \\
\text { blood }\end{array}$ & $\begin{array}{l}\text { i.v. } \\
\text { i.v. }\end{array}$ & $\begin{array}{l}1.88 \\
1.54\end{array}$ & 1.22 & 0.68 & 0.28 & 2.46 & 72 & 0.88 \\
\hline & I & 2.95 & cas. hyd. & i.v. & 3.16 & 1.07 & 1.07 & 0 & 2.09 & 66 & 0.71 \\
\hline & II & 3.00 & cas. hyd. & oral & 1.59 & 0.53 & 0.45 & 0.15 & 1.14 & 72 & 0.38 \\
\hline & II & 3.00 & $\begin{array}{l}\text { cas. hyd. } \\
\text { blood }\end{array}$ & $\begin{array}{l}\text { oral } \\
\text { i.v. }\end{array}$ & $\begin{array}{l}1.40 \\
1.75\end{array}$ & 1.05 & 0.60 & 0.15 & 2.40 & 77 & 0.80 \\
\hline & III & 3.16 & c.h.f. & oral & 1.20 & 0.38 & 0.62 & 0.21 & 0.37 & 31 & 0.12 \\
\hline \multirow{4}{*}{$\begin{array}{l}\text { S. P. } \\
1 \\
\text { month }\end{array}$} & I & 3.24 & cas. hyd. & i.v. & 2.60 & 0.80 & 0.88 & 0.16 & 1.56 & 60 & 0.48 \\
\hline & II & 3.24 & cas. hyd. \{ & $\begin{array}{l}\text { i.v. } \\
\text { oral }\end{array}$ & $\begin{array}{l}0.18 \\
2.25\end{array}$ & 0.75 & 0.85 & 0.51 & 1.07 & 44 & 0.33 \\
\hline & III & 3.30 & $\begin{array}{l}\text { c.h.f. } \\
\text { blood }\end{array}$ & $\begin{array}{l}\text { oral } \\
\text { i.v. }\end{array}$ & $\begin{array}{l}0.60 \\
2.17\end{array}$ & 0.84 & 0.55 & 0.60 & 1.62 & 59 & 0.49 \\
\hline & III & 3.30 & c.h.f. & oral & 0.908 & 0.27 & 0.95 & 0.29 & -0.34 & & -0.10 \\
\hline \multirow{5}{*}{$\begin{array}{l}\text { E. P. } \\
\text { months }\end{array}$} & I & 6.00 & cas. hyd. & i.v. & 3.10 & 0.51 & 3.31 & 0.40 & -0.61 & & -0.10 \\
\hline & II & 6.00 & cas. hyd. \{ & $\begin{array}{l}\text { i.v. } \\
\text { oral }\end{array}$ & $\begin{array}{l}0.28 \\
5.46\end{array}$ & 0.96 & 2.11 & 0.27 & 3.36 & 58 & 0.56 \\
\hline & II & 6.40 & cas. hyd. & oral & 5.58 & 0.87 & 3.48 & 0.30 & 1.80 & 32 & 0.28 \\
\hline & III & 6.70 & $\begin{array}{l}\text { cas. hyd. } \\
\text { c.h.f. }\end{array}$ & $\begin{array}{l}\text { oral } \\
\text { oral }\end{array}$ & 3.78 & 0.56 & 2.94 & 0.32 & 0.52 & 14 & 0.08 \\
\hline & III & 6.50 & c.h.f. & oral & 1.75 & 0.27 & 1.70 & 0.27 & -0.22 & & -0.03 \\
\hline
\end{tabular}


TABLE I-Continued

\begin{tabular}{|c|c|c|c|c|c|c|c|c|c|c|c|}
\hline \multicolumn{3}{|c|}{ Subject } & \multicolumn{4}{|c|}{ Intake* } & \multicolumn{2}{|c|}{ Output } & \multicolumn{3}{|c|}{ Balance } \\
\hline $\begin{array}{l}\text { Name and } \\
\text { age }\end{array}$ & Phaset & Weight & Material & Method & N per day & $\begin{array}{l}\text { N per } \\
\text { kgm. per } \\
\text { day }\end{array}$ & Urine & Feces & $\mathbf{N}$ per day & $\begin{array}{l}N_{\text {of per cent }} \\
\text { of intake }\end{array}$ & $\begin{array}{l}\text { N per } \\
\text { kgm. per } \\
\text { day }\end{array}$ \\
\hline \multirow{2}{*}{$\begin{array}{c}\text { W. } \\
\text { McG. } \\
\text { 5 } \\
\text { weeks }\end{array}$} & III & $\begin{array}{l}\text { kgm. } \\
3.16\end{array}$ & $\begin{array}{c}\text { fat-free milk }+ \\
\text { glucose }\end{array}$ & oral & $\begin{array}{l}\text { srams } \\
1.27\end{array}$ & $\begin{array}{l}\text { erams } \\
0.42\end{array}$ & $\begin{array}{l}\text { erams } \\
0.49\end{array}$ & $\begin{array}{l}\text { srams } \\
0.24\end{array}$ & $\begin{array}{r}\text { erams } \\
0.54\end{array}$ & 42 & $\begin{array}{r}\text { grams } \\
0.17\end{array}$ \\
\hline & I & 2.83 & cas. hyd. & i.v. & 2.37 & 0.84 & 1.27 & 0.06 & 1.04 & 43 & 0.37 \\
\hline J. J. & I & 6.90 & cas. hyd. & i.v. & 2.80 & 0.41 & 2.65 & 0.45 & -0.30 & & -0.04 \\
\hline \multirow{2}{*}{$\begin{array}{c}\text { A. B. } \\
3 \\
\text { weeks }\end{array}$} & I & 3.26 & cas. hyd. & i.v. & 2.08 & 0.64 & 1.35 & 0.26 & 0.47 & 23 & 0.14 \\
\hline & I & 3.10 & cas. hyd. & i.v. & 1.67 & 0.54 & 1.04 & 0.11 & 0.52 & 31 & 0.17 \\
\hline $\begin{array}{l}\text { S. K. K } \\
4 \text { weeks }\end{array}$ & I & 2.64 & cas. hyd. & i.v. & 1.57 & 0.60 & 1.27 & 0.04 & 0.26 & 17 & 0.10 \\
\hline $\mathrm{W.}_{\mathbf{5}}^{\mathrm{T}}$ & I & 5.33 & cas. hyd. & i.v. & 2.50 & 0.47 & 2.05 & 0.33 & 0.12 & 4 & 0.02 \\
\hline $\begin{array}{c}\text { J. diB. } \\
7 \\
\text { weeks }\end{array}$ & II & 3.69 & cas. hyd. & $\begin{array}{l}\text { i.v. } \\
\text { oral }\end{array}$ & $\begin{array}{l}0.89 \\
0.19\end{array}$ & 0.29 & 0.71 & 0.05 & 0.32 & 30 & 0.09 \\
\hline $\begin{array}{c}\text { R. } H \text {. } \\
\text { months }\end{array}$ & II & 4.90 & cas. hyd. & $\begin{array}{l}\text { i.v. } \\
\text { oral }\end{array}$ & $\begin{array}{l}2.34 \\
0.39\end{array}$ & 0.56 & 2.05 & 0.06 & 0.62 & 25 & 0.13 \\
\hline \multirow{2}{*}{$\begin{array}{c}\text { J. F. } \\
3 \\
\text { weeks }\end{array}$} & II & 3.00 & cas. hyd. & $\begin{array}{l}\text { i.v. } \\
\text { oral }\end{array}$ & $\begin{array}{l}1.75 \\
1.35\end{array}$ & \} 1.03 & 0.73 & 0.12 & 2.25 & 72 & 0.75 \\
\hline & III & 3.23 & c.h.f. & oral & 1.62 & 0.50 & 0.37 & 0.05 & 1.20 & 73 & 0.37 \\
\hline \multirow{2}{*}{$\begin{array}{c}\text { A. W. } \\
18 \\
\text { months }\end{array}$} & III & 9.90 & $\begin{array}{l}\text { cas. hyd. } \\
\text { c.h.f. }\end{array}$ & $\begin{array}{l}\text { i.v. } \\
\text { oral }\end{array}$ & $\begin{array}{l}1.41 \\
3.33\end{array}$ & 0.48 & 1.70 & 0.74 & 2.30 & 49 & 0.23 \\
\hline & III & 10.00 & $\begin{array}{l}\text { cas. hyd. } \\
\text { c.h.f. }\end{array}$ & $\begin{array}{l}\text { i.v. } \\
\text { oral }\end{array}$ & $\begin{array}{l}1.00 \\
3.05\end{array}$ & 0.40 & 2.32 & 1.36 & 0.37 & 9 & 0.04 \\
\hline $\begin{array}{c}\text { J. D. } \\
1 \\
\text { month }\end{array}$ & I & 3.22 & cas. hyd. & i.v. & 2.08 & 0.64 & 0.92 & 0.06 & 1.10 & 53 & 0.34 \\
\hline
\end{tabular}

\section{Controls}

\begin{tabular}{c|c|c|c|c|c|c|c|c|c|c|c}
\hline $\begin{array}{c}\text { T. S. } \\
\text { weeks }\end{array}$ & I & 2.87 & $\begin{array}{c}\text { glucose }+ \text { saline } \\
\text { lactate }\end{array}$ & i.v. & 0 & 0 & 0.61 & 0.12 & -0.73 & -0.25 \\
\hline $\begin{array}{c}\text { J. T. } \\
6 \\
\text { months }\end{array}$ & I & 6.85 & glucose + saline & i.v. & 0 & 0 & 1.15 & 0.25 & -1.40 & -0.21 \\
\hline $\begin{array}{c}\text { R. F. } \\
2 \\
\text { months }\end{array}$ & III & 3.60 & $\begin{array}{c}\text { evap. milk } \\
\text { karo }\end{array}$ & oral & 1.11 & 0.31 & 1.14 & 0.19 & -0.22 & -0.12 \\
\hline $\begin{array}{c}\text { J. W. } \\
3 \text { weeks }\end{array}$ & III & 3.12 & $\begin{array}{c}\text { glucose + saline } \\
\text { evap. milk }\end{array}$ & $\begin{array}{c}\text { i.v. } \\
\text { oral }\end{array}$ & $\begin{array}{l}0 \\
0.52\end{array}$ & $\begin{array}{l}0 \\
0.17\end{array}$ & 0.77 & 0.09 & -0.34 & -0.06 \\
\hline
\end{tabular}

* Abbreviations used are as follows: cas. hyd. = casein hydrolysate solution; c.h.f. = casein hydrolysate food. The composition is given in Footnote 3. i.v. = intravenous administration.

$\dagger$ These periods were irregular in length, varying from 1 to 4 days, and were consecutive. The Phases are numbered according to the type of therapy as follows: Phase I. Intravenous administration only. Phase II. Oral administration or intravenous and oral administration of casein hydrolysate solution. Phase III. Oral administration of casein hydrolysate food or milk formula instead of, or in addition to, casein hydrolysate solution (orally or intravenously). Blood transfusions were given sometimes in either Phase I, Phase II, or Phase III.

$\ddagger$ Weight at beginning of period. \& Estimated to allow for vomiting.

\ Died. 
basis of surface area, basal metabolism, or some other standard. There are 10 cases in which the same phase of treatment continued for 2 successive periods. In nearly all these cases, there was considerable difference in the nitrogen intake, due to blood transfusion or other variation. None were exact duplicates. In all cases, there was a change in the clinical status. For these reasons, the results are given separately rather than as averages.

It will be noted that the infants who received the casein hydrolysate (with or without blood transfusions) in adequate amounts, with one exception (E. P., first period), had positive balances. Even the 2 infants who were moribund (W. McG. and S. K.) showed good nitrogen retentions. On the other hand, the controls were in negative nitrogen balance. T. S. and J. T., who received glucose-saline solution only, had losses of the same order of magnitude as those previously reported for infants who had received no nitrogen, but liberal carbohydrate intakes (1, 3). R. F. and J. W., who were given milk formulas, also were in negative nitrogen balance. Their nitrogen intakes were low, but it was judged that no more could be tolerated because of the infants' clinical condition, which, moreover, was not as severe as that represented by the periods of observation recorded in Phase I for the other infants in this study.

The distribution of nitrogen in the excreta did not differ greatly from that found in normal babies. Even with infants who have diarrhea and are receiving intravenous therapy, fecal nitrogen is, in per cent of total output, no greater than in normal infants, 13.6 and 11.4 respectively (1). If the dry weight of the feces was high, the nitrogen excretion was high. The nitrogen forms a roughly constant proportion of from 2 to 7 per cent of the dry weight of the feces. This holds true of diarrheal stools and normal stools of infants fed parenterally and orally, whether given casein hydrolysate or milk. Furthermore, diarrheal stools do not show a great increase of nitrogen or of dry material; the main difference between them and normal stools lies in the water and salt content.

A brief summary of the data on nitrogen retention in Table I is given in Table II, arranged according to three levels of intake, irrespective of
TABLE II

Average nitrogen balance with different levels of nitrogen intake, calculated from the data in Table I

\begin{tabular}{|c|c|c|c|c|c|}
\hline \multirow{2}{*}{$\begin{array}{c}\text { Num- } \\
\text { ber } \\
\text { of } \\
\text { cases }\end{array}$} & \multicolumn{2}{|c|}{ Nitrogen intake } & \multirow{2}{*}{\multicolumn{3}{|c|}{ Nitrogen balance }} \\
\hline & Range & Average & & & \\
\hline & $\begin{array}{l}\text { grams per } \\
\text { kgm. per day }\end{array}$ & $\begin{array}{l}\text { grams per } \\
\text { kgm. per } \\
\text { day }\end{array}$ & $\begin{array}{l}\text { grams } \\
\text { per day }\end{array}$ & $\begin{array}{l}\text { grams per } \\
\text { kgm. per } \\
\text { day }\end{array}$ & $\begin{array}{l}\text { per cent of } \\
\text { intake }\end{array}$ \\
\hline $\begin{array}{r}6 \\
21 \\
14\end{array}$ & $\begin{array}{l}0.27 \text { to } 0.35 \\
0.36 \text { to } 0.65 \\
0.66 \text { to } 1.28\end{array}$ & $\begin{array}{l}0.31 \\
0.50 \\
0.92\end{array}$ & $\begin{array}{r}-0.03 \\
0.85 \\
2.07\end{array}$ & $\begin{array}{r}-0.01 \\
0.16 \\
0.50\end{array}$ & $\begin{array}{l}32 \\
54\end{array}$ \\
\hline
\end{tabular}

whether the nitrogen was ingested or injected. Retention is shown to be correlated with intake. With the amounts of nitrogen used in this study, when the intake is larger, the retention is larger also, but is not a constant fraction of the intake. A nitrogen intake greater than the amount of wastage is necessary to keep the individual in equilibrium. The average excretion of the controls, T. S. and J. T., was 0.19 gram per $\mathrm{kgm}$. of body weight, whereas the amount of nitrogen necessary to maintain equilibrium is about 0.35 gram per kgm., which is equivalent to 2.8 grams of casein hydrolysate, or 2.2 grams of protein.

One case who received more than 0.35 gram of nitrogen had a small negative balance (E. P., first period), one was in equilibrium (J. J.), and 2 cases with intakes below this figure had small positive balances. Even in these sick children, positive balances were obtained with intakes as low as 0.29 (J. diB.) and 0.30 (R. C.). But 0.4 to 0.5 gram per $\mathrm{kgm}$. of body weight is the minimum one would expect to use clinically.

There was only one case (E. P., first period) of negative balance when casein hydrolysate was given intravenously in sufficient amounts. The infant was in acidosis during this one-day period, the bicarbonate concentration of the plasma being 19 m.eq. per liter, which probably accounts for the extraordinarily high nitrogen excretion in the urine. Moreover, in the 3 day period immediately following, very high nitrogen retention was obtained.

In this series of cases, a number of blood transfusions were given. Presumably the plasma proteins thus introduced intravenously serve as an excellent source of nitrogen for nutrition (4). Even if they are not catabolized, but are used to build up depleted plasma proteins, it is still proper, in our opinion, to consider this nitrogen as re- 
tained, for the same end result is reached directly, as that attained indirectly when proteins or amino acids are fed by mouth. In some cases, the transfusion supplemented an otherwise inadequate nitrogen intake, and in others, was added to a sufficient intake. For example, in the former case, the nitrogen balance would have been negative without the transfusion (D. D., second period), but in the latter, would have been positive without transfusion, and was rendered exceptionally high by the addition of the blood plasma (R. McK., second period).

The group with the highest nitrogen intake (see Table II) showed retentions which exceeded, both in amount and in proportion of intake, the retentions which may be expected in well infants. A normal infant on a milk formula diet usually retains about 25 per cent of the nitrogen ingested, shows a total retention of about 0.5 to 1.5 grams per day, or 0.17 gram per $\mathrm{kgm}$. of body weight This value, taken from our previous experience (1) agrees with the data in Czerny-Keller (5). The average proportion of intake retained by the sick infants in this study was 45 per cent, the highest 77 per cent (R. McK., fifth period); the highest actual retention was 4.0 grams per day (R. C., third period), and the highest retention per $\mathrm{kgm}$. of body weight per day was 0.88 gram (R. McK., second period).

The high retentions may be attributed in part to larger intakes and in part to the fact that the nitrogen which had undergone previous depletion was now being restored. The previous loss from the tissues may have been due in part to lack of ability to digest or absorb protein, as well as to the withholding of food. It is easier to restore losses than to make new gains. Moreover, casein hydrolysate is more rapidly absorbed than unhydrolyzed protein (6).

Nitrogen retentions were not correlated with gains in weight. Although each gram of nitrogen retained carries with it approximately 6 times its weight of protein, or 30 times its weight of body substance, the body weight fluctuations depend primarily upon the state of hydration, rather than upon nitrogen accretion. One of the features of nutritional disturbances of this type is great loss of weight due to dehydration. It is therefore not uncommon for these cases to show astounding weight gains during recovery, of the order of a kilogram or more in a few days. Some of this represents fluid replaced and some of it fluid which will subsequently be eliminated. These gains may be as much as 25 times the gain normally accompanying nitrogen retention of the order obtained in this study. The weights given in Table $I$ were the weights at the beginning of each period, and the periods being of unequal length, they do not represent 24-hour gains.

Although increased body temperature has a tendency to increase protein catabolism, the effect in these cases was not marked. Although no attempt has been made to correlate nitrogen balance with temperature elevation, the loss of protein in the controls was not in excess of that of normal infants deprived of their nitrogen intake, and the positive balances of the cases studied were not less than might have been expected if no fever had been present.

Retentions were greater, both in amount and in proportion to the intake, when blood transfusions were given in conjunction with casein hydrolysate.

Whether the casein hydrolysate was administered intravenously, intravenously and orally, or orally, i.e., whether the disease was in its most acute phase, a less acute phase, or the recovery phase, nitrogen retentions were approximately the same at the same levels of intake.

The present study shows that acute gastrointestinal disturbance does not hinder retention of nitrogen when administered in proper form and amount. The fact that these infants had good nitrogen balances when casein hydrolysate was given, but did not when saline-glucose solution or milk was given, is sufficient proof that casein hydrolysate administration is desirable. Other things being equal, the more nearly the normal physiological status can be approximated, the more adequate is the treatment. That it is better to prevent loss than to have to repair it, does not have to be shown by statistical treatment of clinical details.

\section{SUMMARY}

1. Infants with acute gastro-intestinal disturbance involving vomiting, diarrhea, dehydration, and acidosis, were able to retain nitrogen when it was given in adequate amounts in the form of casein hydrolysate, either intravenously or orally or both. 
2. Positive nitrogen balances were obtained when the nitrogen intake was 0.35 gram per $\mathrm{kgm}$. of body weight per day.

3. Retentions were greater when nitrogen intakes were greater, and were as large as those reported for well infants.

The author wishes to acknowledge the assistance of Dr. G. L. Brooks, who supervised the care of the infants; other members of the House Staff, who gave the intravenous injections; Miss Harriet O'Hara, who was the nurse in charge; and Miss Dorothy Cohen, who made the nitrogen determinations.

\section{BIBLIOGRAPHY}

1. Shohl, A. T., Butler, A. M., Blackfan, K. D., and MacLachlan, E., Nitrogen metabolism during the oral and parenteral administration of the amino acids of hydrolyzed casein. J. Pediat., 1939, 15, 469.

2. Hill, L. W., Amino acids as a source of nitrogen for allergic infants. J. A. M. A., 1941, 116, 2135.

3. Shohl, A. T., and Blackfan, K. D., The intravenous administration of crystalline amino acids to infants. J. Nutrition, 1940, 20, 305.

4. Madden, S. C., and Whipple, G. H., Plasma proteins : their source, production and utilization. Physiol. Rev., 1940, 20, 194.

5. Czerny, A., and Keller, A., Des Kindes Ernährung, Ernährungsstorungen und Ernährungstherapie. F. Deuticke, Leipzig and Vienna, 1923-28, 2nd ed., vol. 1 , pp. $689-709$; vol. 2, pp. 514-535.

6. McGee, L. C., and Emery, E. S., Jr., The rate of absorption of amino acids from the small intestine in man. Proc. Soc. Exper. Biol. and Med., 1940, 45, 475. 